\title{
Control of Membrane Fouling by Coagulant and Coagulant Aid Addition in Membrane Bioreactor Systems
}

\author{
Tuyet T. TRAN*, Md. SHAFIQUZZAMAN*, Jun NAKAJIMA* \\ * Department of Environmental Systems Engineering, Faculty of Science and Engineering, \\ Ritsumeikan University, 1-1-1 Nojihigashi, Kusatsu 525-8577, Japan.
}

\begin{abstract}
The mixture of polysilicate and Fe(III), and commercial polysilicato-iron (PSI) were employed to control membrane fouling risk. Batch experiments and long-term membrane bioreactor (MBR) experiments were conducted with the addition of 1) polysilicate, 2) mixtures of polysilicate and $\mathrm{Fe}(\mathrm{III})$ with various ratios, and 3) sole Fe(III) and commercial PSI with two available molar ratios, $\mathrm{Fe} / \mathrm{Si}=1: 1$ (PSI-100) and $\mathrm{Fe} / \mathrm{Si}=1: 0.25$ (PSI-025). Sole polysilicate addition in MBR showed no effect on controlling membrane fouling risk, while the mixture of polysilicate and $\mathrm{Fe}(\mathrm{III})$ could yield some advantages at a specific combination, $90 \mathrm{mg} / \mathrm{L} \mathrm{Fe}$ (III) with $5 \mathrm{mg} / \mathrm{L} \mathrm{Si}$ for batch experiment, and $45 \mathrm{mg} / \mathrm{L} \mathrm{Fe}(\mathrm{III})$ with $20 \mathrm{mg} / \mathrm{L} \mathrm{Si}$ for long-term MBR experiment. On the other hand, the higher efficiency of biopolymer removal was attained by the addition of PSI in batch experiments. Furthermore, the membrane fouling frequencies were reduced and the concentrations of protein and carbohydrate in soluble microbial products (SMP less than $1 \mu \mathrm{m}$ ) were largely diminished by the addition of PSI in long-term MBR experiments. These results suggested that PSI would be useful to control membrane fouling problem and enhance the performance of membrane filtration.
\end{abstract}

Keywords: coagulants, fouling, MBR, mixture of polysilicate and Fe(III), polysilicato - iron (PSI).

\section{INTRODUCTION}

Membrane bioreactor (MBR) technology combines the biological degradation process by activated sludge with a direct solid-liquid separation by membrane filtration. Through micro or ultrafiltration membrane technology (with pore sizes ranging from 0.05 to $0.4 \mu \mathrm{m}$ ), MBR system allows the complete physical retention of bacterial flocs and virtually all suspended solids within the bioreactor (Le-Clech et al., 2006; Tran et al., 2006; Mishima and Nakajima, 2009). The MBR has brought several advantages for conventional wastewater treatment process, including stable and high effluent quality, good disinfection capability, and less excess sludge production (Mishima and Nakajima, 2003; Le-Clech et al., 2006; Meng et al., 2009).

However, membrane fouling, which results in the reduction of permeate flux or an increase of transmembrane pressure (TMP), is still the most serious problem in this process (Jarusutthirak and Amy, 2006; Arabi and Nakhal, 2008; Wu et al., 2006; Yu et al., 2006). According to Zhang et al. (2008), several factors have been found to affect membrane fouling, including floc size, viscosity of mixed liquor, and especially soluble microbial products (SMP). SMP are compounds of microbial origin which are derived during biological processes of wastewater treatment (Drews et al., 2007; Ichihashi et al., 2006). They exhibit the characteristics of hydrophilic organic colloids and macromolecules. These high molecular weight compounds play an important role in creating high resistance on the membrane, and lead to a reduction of permeate flux or an

Address correspondence to Jun Nakajima, Department of Environmental Systems Engineering, Faculty of Science and Engineering, Ritsumeikan University, Email: jnt07778@se.ritsumei.ac.jp

Received May 7, 2010, Accepted July 7, 2010. 
increase of TMP (Jarusutthirak and Amy, 2006; Drews et al., 2008; Aquino and Stuckey, 2008). Therefore, SMP is considered as the most important factor causing membrane fouling (Meng and Yang, 2007).

Almost all colloids found in activated sludge carry negative charge (Zouboulis and Moussas, 2008). Thus, addition of cations like aluminum-based or iron-based coagulants can enhance the filterability of the mixed liquor in the MBR because these ions neutralize the charge of sludge (Fu and Yu, 2007; Xu et al., 2009; Fu et al., 2007; Song et al., 2008). According to Mishima and Nakajima (2009), the addition of Fe(III) coagulant was found to have a higher efficiency than that of aluminum sulfate in MBR. The polyferric coagulant was observed to be more effective than conventional coagulants (Zouboulis and Moussas, 2008; Fu et al., 2007; Wang and Tang, 2001). Furthermore, the addition of polyferric coagulant could control both the irreversible fouling and suspension viscosity (Le-Clech et al., 2006).

Sometimes, coagulant aid was added to Fe(III) to increase the ability of sludge dewatering, so polysilicate addition to Fe(III) was thought to be also useful to increase bridge-aggregation ability in MBR system. Therefore, mixture of polysilicate and $\mathrm{Fe}(\mathrm{III})$ was used in this study. Behaviors of these materials on biopolymer (protein and carbohydrate) removal and fouling reduction were investigated by conducting batch and long-term MBR experiments. The main goals of adding such modified coagulants were to increase particle size, and to enhance the aggregation ability of the conventional coagulants.

\section{MATERIALS AND METHODS}

\section{Preparation of coagulants and coagulant aids}

Sodium silicate $\left(\mathrm{Na}_{2} \mathrm{SiO}_{3}\right.$, anhydrous $)$ used as coagulant aid was diluted with distilled water and then neutralized to $\mathrm{pH} 7.0$ by $\mathrm{HCl}$ and $\mathrm{NaOH}$ solutions. Iron (III) chloride hexahydrate $\left(\mathrm{FeCl}_{3} \cdot 6 \mathrm{H}_{2} \mathrm{O}\right)$ used as coagulant was also diluted and mixed with the diluted sodium silicate solution to get the final mixtures with different ratios of Fe(III) and polysilicate. Commercial polysilicato-iron (PSI, Suidokiko, Japan) solution with two available molar ratios, PSI-025 $(\mathrm{Fe} / \mathrm{Si}=1: 0.25)$ and PSI-100 $(\mathrm{Fe} / \mathrm{Si}=1: 1)$, was used as coagulants. They were also diluted with distilled water to get the final solution in which the concentration of Fe (III) was $45 \mathrm{mg} / \mathrm{L}$.

\section{Batch experiments}

The aim of these experiments was to investigate the effect of coagulant and coagulant aid additions on the biopolymer removal, especially protein and carbohydrate. Herein, commercial albumin (from egg) and glycogen (from oyster) were diluted to get the original concentration of protein and carbohydrate at $100 \mathrm{mg} / \mathrm{L}$, respectively. The commercial albumin or glycogen solution was then respectively mixed with different coagulants and coagulant aid in $200 \mathrm{ml}$ beaker. After 15 minutes of mixing at $30 \mathrm{rpm}$ by a jar test apparatus, the mixing solution was filtered through filter paper $(1 \mu \mathrm{m}$ pore size, Advantec 5C) and was measured for protein and carbohydrate concentrations. The mixing duration (15 minutes) was decided from the results of kinetic batch experiments. The $\mathrm{pH}$ of all solutions of the batch experiments were controlled to $7.0 \mathrm{using} \mathrm{HCl}$ and $\mathrm{NaOH}$ solutions during the preparation process. 


\section{Long-term MBR experiments}

Fig. 1 shows the schematic diagram of a typical laboratory-scale MBR experiment. Each reactor was made of plexiglass and had a designed working volume of $10 \mathrm{~L}$. A flat sheet membrane made of chlorinated polyethylene $(0.4 \mu \mathrm{m}$ nominal pore size and 0.04 $\mathrm{m}^{2}$ filtration area, Kubota, Japan) was submerged into the reactor, which was intermittently operated under $1.5 \mathrm{~h}$ aerobic and $0.5 \mathrm{~h}$ anaerobic conditions at $25^{\circ} \mathrm{C}$. Air was supplied from an aeration pipe below the membrane module at $3 \mathrm{~L} / \mathrm{min}$ to provide oxygen for biomass growth and to create sufficient turbulence along the membrane surface. Mixture of concentrated coagulant and its aid or sole polysilicate solution was added to the reactor for $15 \mathrm{~min}$ every $2 \mathrm{~h}$ at $1.1 \mathrm{~mL} / \mathrm{min}$. Simultaneously, $\mathrm{NaHCO}_{3}$ solution $(1.25 \%)$ was added at the same flow rate and duration, except for the experiments with sole polysilicate addition, in order to control the $\mathrm{pH}$. The filtration was carried out with the flux set at $0.25 \mathrm{~m}^{3} / \mathrm{m}^{2} /$ day. The suction pump was also intermittently operated by keeping it on for $1.5 \mathrm{~h}$ and off for $0.5 \mathrm{~h}$. The membranes were washed (physical washing by tap water while wiping the membrane with hand or chemical washing by submerging the membrane in $0.25 \% \mathrm{NaOCl}$ solution for 1 to $2 \mathrm{~h}$ ) when the pressure of the suction pump decreased to less than -0.03 MPa.

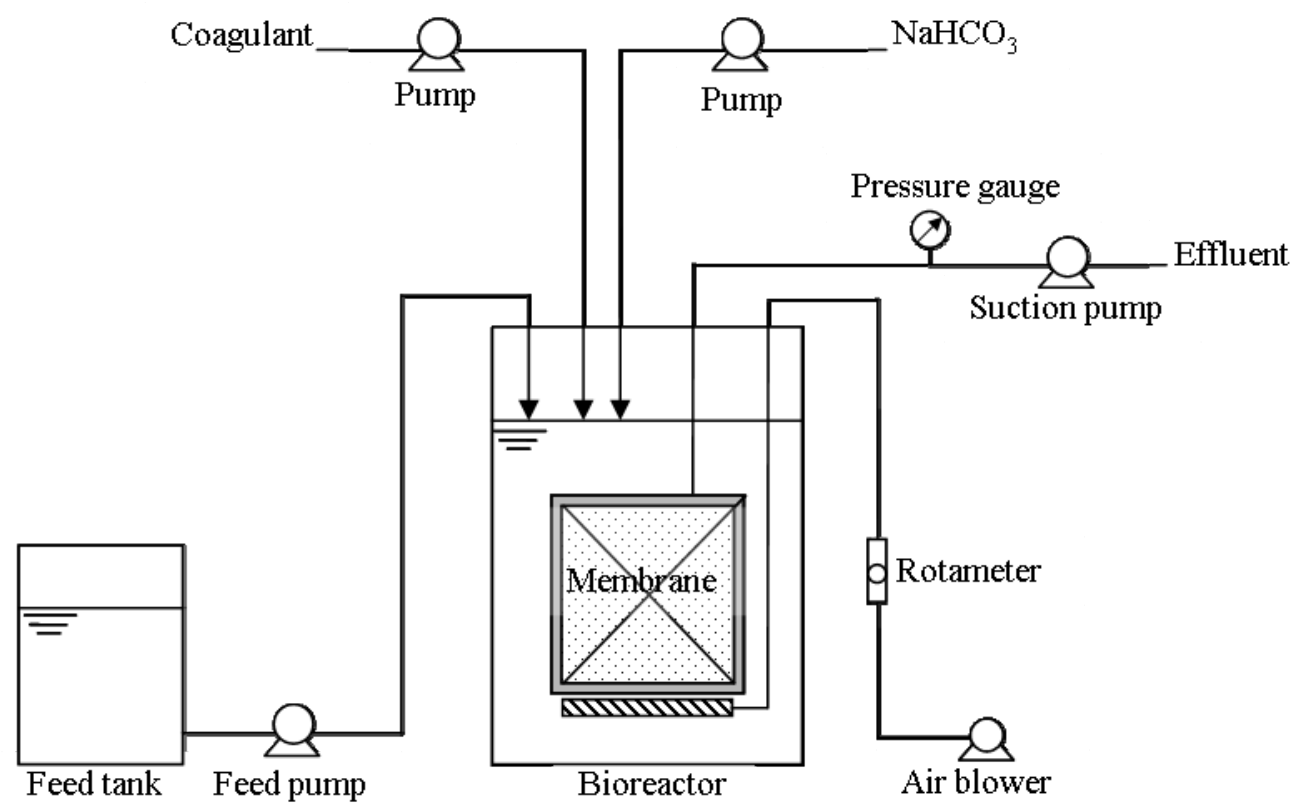

Fig. 1 - Schematic diagram of the long-term MBR experiment.

Table 1 - Components of synthetic wastewater.

\begin{tabular}{|c|c|c|c|}
\hline Components & $\begin{array}{l}\text { Concentration } \\
(\mathrm{mg} / \mathrm{L})\end{array}$ & $\begin{array}{l}\text { Influent water } \\
\text { quality }\end{array}$ & $\begin{array}{l}\text { Concentration } \\
(\mathrm{mg} / \mathrm{L})\end{array}$ \\
\hline Glucose & 1233.33 & BOD & 1000 \\
\hline Sodium L $(+)$-glutamate & 603.33 & Nitrogen & 50 \\
\hline monohydrate & & Phosphorus & 25 \\
\hline $\mathrm{NaCl}$ & 16.67 & & \\
\hline $\mathrm{CaCl}_{2} \cdot 2 \mathrm{H}_{2} \mathrm{O}$ & 11 & & \\
\hline $\mathrm{MgSO}_{4}$ & 10.5 & & \\
\hline $\mathrm{K}_{2} \mathrm{HPO}_{4}$ & 106.67 & & \\
\hline $\mathrm{KH}_{2} \mathrm{PO}_{4}$ & 26.67 & & \\
\hline $\mathrm{NaHCO}_{3}$ & 105 & & \\
\hline
\end{tabular}


Mixed liquor taken from an actual MBR facility treating domestic wastewater $(1,000$ population equivalents) in Kusatsu City, Japan, was used in all long-term MBR experiments. Synthetic wastewater (Table 1) was fed into each reactor at $10 \mathrm{~L} /$ day with $1,000 \mathrm{mg} / \mathrm{L}$ of biological oxygen demand (BOD), $50 \mathrm{mg} / \mathrm{L}$ of nitrogen and $25 \mathrm{mg} / \mathrm{L}$ of phosphorus. The experiments were conducted at a sludge retention time (SRT) of 33 days and the hydraulic retention time (HRT) was almost 24h. The corresponding concentration of mixed liquor suspended solid (MLSS) in the reactors were around 10,000 to $14,000 \mathrm{mg} / \mathrm{L}$.

Table 2 shows the list of coagulants and/or coagulant aid, which were used in the longterm MBR experiments. Every three MBR was operated simultaneously to clarify and to compare the behavior among the coagulants and coagulant aid.

Table 2 - Conditions of coagulants and coagulant aid in long-term MBR experiments

\begin{tabular}{l|ccc:ccc:ccc}
\hline \multicolumn{1}{c}{ Runs } & \multirow{2}{*}{ R1 } & R2 & R3 & R4 & R5 & R6 & R7 & R8 & R9 \\
\hline Polysilicate (mg/L) & $\times$ & 10 & 20 & 10 & 20 & 50 & $\times$ & $\times$ & $\times$ \\
Fe (mg/L) & $\times$ & $\times$ & $\times$ & 45 & 45 & 45 & 45 & $\times$ & $\times$ \\
PSI-100 (mg Fe/L / mg Si/L) & $\times$ & $\times$ & $\times$ & $\times$ & $\times$ & $\times$ & $\times$ & $45 / 49.5$ & $\times$ \\
PSI-025 (mg Fe/L / mg Si/L) & $\times$ & $\times$ & $\times$ & $\times$ & $\times$ & $\times$ & $\times$ & $\times$ & $45 / 12$ \\
\hline
\end{tabular}

\section{Analytical methods}

Protein and carbohydrate concentrations were measured using Lowry's method and the anthrone-sulfuric acid reaction, respectively. Iron and silicate were determined by an inductively coupled plasma emission spectrometry (SPS 4000, Seiko, Japan) after the digestion of organics using nitric acid and hydrogen peroxide. The extracellular polymeric substances (EPS) of the mixed liquor were extracted by steam treatment at $105{ }^{\circ} \mathrm{C}$ for 30 minutes (Nakajima and Mishima, 2005). For the SMP $<0.4 \mu \mathrm{m}$ and SMP of $0.4 \sim 1 \mu \mathrm{m}$, measurement of the amount of protein and carbohydrate in the effluent and mixed liquor filtered by filter paper $(1 \mu \mathrm{m}$ pore size, Advantec $5 \mathrm{C})$ was done. Chemical oxygen demand (COD) was measured using $\mathrm{KMnO}_{4}$ oxidization. Quantitative analyses of other parameters were carried out according to JIS K0102.

\section{RESULTS AND DISCUSSION \\ Batch experiments}

Biopolymer removal by polysilicate and $\mathrm{Fe}(I I I)$ addition

Fig. 2 shows the results obtained from the batch experiments, which were conducted using sole polysilicate and different ratios of polysilicate and Fe (III). It can be seen that without $\mathrm{Fe}$ (III) addition the carbohydrate concentration remained stable. However, in the case of protein, it slightly increased from $85 \mathrm{mg} / \mathrm{L}$ to $91 \mathrm{mg} / \mathrm{L}$ with 0 and $5 \mathrm{mg} / \mathrm{L}$ polysilicate addition, respectively. After that, it remained stable. Since in neutral media both the biopolymers and polysilicate carry minus charge (Duan and Gregory, 2003) they do not react with each other. This suggested that sole polysilicate would have no effect on the biopolymer removal.

On the other hand, the mixture of Fe(III) and polysilicate worked more effectively on protein and carbohydrate removal. The removal amount increased according to the 
increase in $\mathrm{Fe}(\mathrm{III})$ concentrations. Particularly, the protein concentrations decreased and were $85 \mathrm{mg} / \mathrm{L}, 46 \mathrm{mg} / \mathrm{L}$ and $23 \mathrm{mg} / \mathrm{L}$ at 0,45 and $90 \mathrm{mg} / \mathrm{L} \mathrm{Fe}(\mathrm{III})$ without polysilicate, respectively. For these conditions, the carbohydrate concentrations were found to be 95 , 55 and $34 \mathrm{mg} / \mathrm{L}$, respectively. The optimum combination of $\mathrm{Fe}(\mathrm{III})$ and polysilicate seemed to exist at $5 \mathrm{mg} / \mathrm{L}$ polysilicate and $90 \mathrm{mg} / \mathrm{L} \mathrm{Fe}(\mathrm{III})$ with protein and carbohydrate concentrations of 9 and $32 \mathrm{mg} / \mathrm{L}$, respectively. Therefore, the presence of polysilicate in the mixtures seemed to serve as a bridge to enhance the aggregation of conventional Fe(III) coagulant.
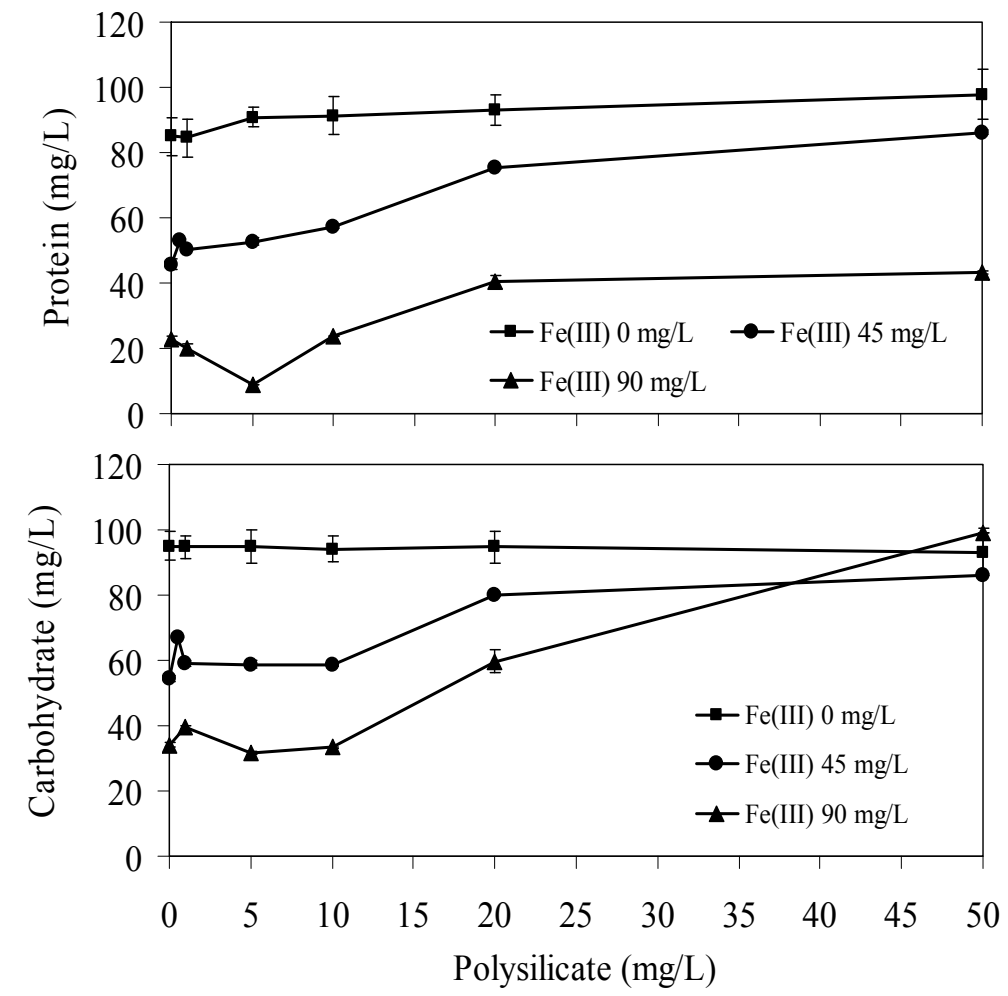

Fig. 2 - Biopolymer removal by sole Fe(III), mixtures of polysilicate addition. (Error bars show the standard deviation of 3 samples)

\section{Biopolymer removal by PSI addition}

Table 3 shows the results of protein and carbohydrate removals by PSI-025 (45 mg Fe/L and $12 \mathrm{mg} \mathrm{Si} / \mathrm{L}$ ) and PSI-100 (45 mg Fe/L and $49.5 \mathrm{mg} \mathrm{Si} / \mathrm{L})$ additions. The standard deviations were calculated from 3 samples. Protein and carbohydrate removals were about $37 \%-48 \%$ and $25 \%-36 \%$, respectively. The biopolymer removal by PSI- 025 addition was significantly higher than PSI-100 addition $(\mathrm{p}=0.022)$. However, both PSI additions showed effectiveness in biopolymer removal.

Table 3 - Protein and carbohydrate removal by PSI additions (\%)

\begin{tabular}{lccc}
\hline & No addition & PSI-100 addition & PSI-025 addition \\
\hline Protein & 0 & $37 \pm 3.8$ & $48 \pm 3.6$ \\
Carbohydrate & 0 & $25 \pm 1.5$ & $36 \pm 0.6$ \\
\hline
\end{tabular}




\section{Long-term MBR experiments}

\section{Effluent water quality}

The BOD and COD removal in R1 to R9 were almost stable at $99.7 \%$ to $99.9 \%$ and $96.7 \%$ to $98.7 \%$, respectively. These values indicated that BOD and COD were removed effectively due to the performance of membrane filter and the biological degradation process of activated sludge in MBR and there was no significant difference among 9 runs.

\section{TMP profiles of MBR experiments with polysilicate addition}

Fig. 3 shows the behavior of polysilicate in controlling membrane fouling in three MBR systems (R1, R2, and R3). TMP was increased by membrane clogging and recovered by physical washing. The concentrations of sole polysilicate addition employed in the current experiments were $0 \mathrm{mg} / \mathrm{L}$ (R1), $10 \mathrm{mg} / \mathrm{L}$ (R2), and $20 \mathrm{mg} / \mathrm{L}$ (R3). It can be seen that the fouling frequency found in the three MBR systems were almost similar during the 35 days of operation. Moreover, the mean periods per one washing in R1, R2, and $\mathrm{R} 3$ were $1.0 \pm 0.5$ day, $0.63 \pm 0.4$ day, and $0.88 \pm 0.6$ day, respectively. These results suggested that sole polysilicate addition has no effect on membrane fouling mitigation.

a)

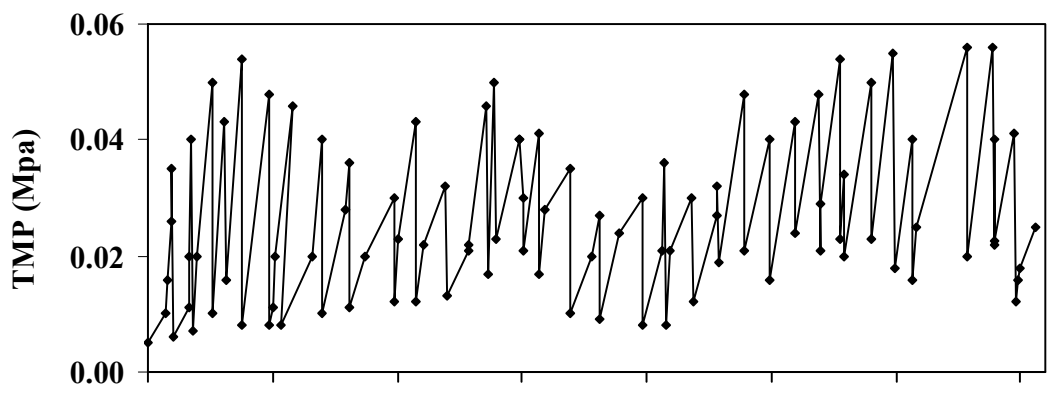

b)

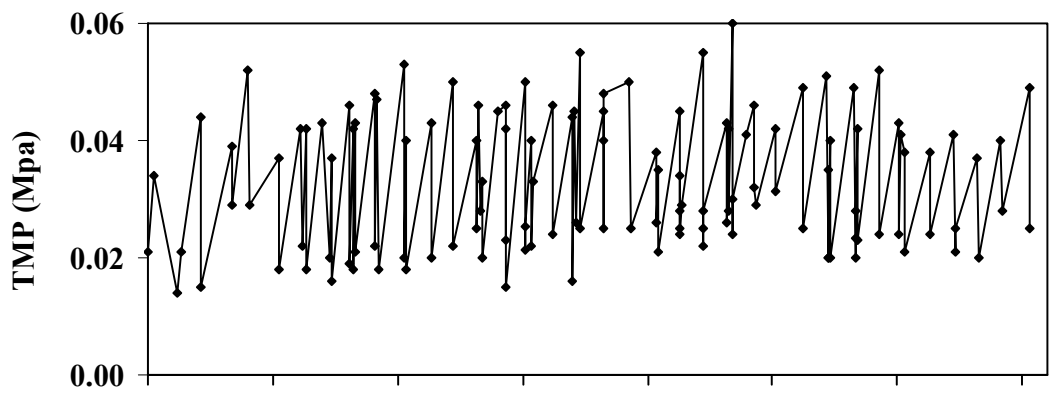

c)

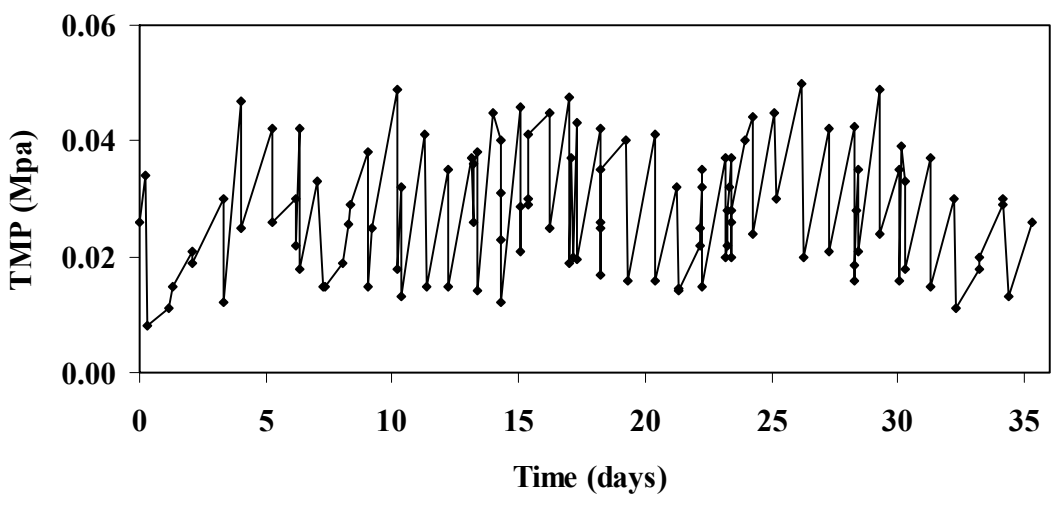

Fig. 3 - TMP profiles of MBR at a) R1, b) R2 and c) R3. 
TMP profiles of MBR experiments with Fe(III) and polysilicate combinations addition

The fouling frequencies shown in Fig. 4 resulted when mixtures of $\mathrm{Fe}$ (III) and polysilicate were used (R4, R5, R6). In the case of R5, where the mixture contained 20 $\mathrm{mg} \mathrm{Si} / \mathrm{L}$ and $45 \mathrm{mg} \mathrm{Fe}(\mathrm{III}) / \mathrm{L}$, the clogging frequency seemed to be decreased as compared to the others. Moreover, the mean fouling periods of R4, R5, R6 and R7 (sole $\mathrm{Fe}$ (III) addition) were also calculated. The longest period, 1.52 days per one washing, was obtained in R5 while in other cases it was less than 1 day. This result suggested that adding polysilicate and $\mathrm{Fe}(\mathrm{III})$ mixture would bring better effect to mitigate membrane fouling problems under suitable ratio and condition. In this study, the combination of 20 $\mathrm{mg} \mathrm{Si} / \mathrm{L}$ and $45 \mathrm{mg} \mathrm{Fe}(\mathrm{III}) / \mathrm{L}$ could give better results than the others.

a)

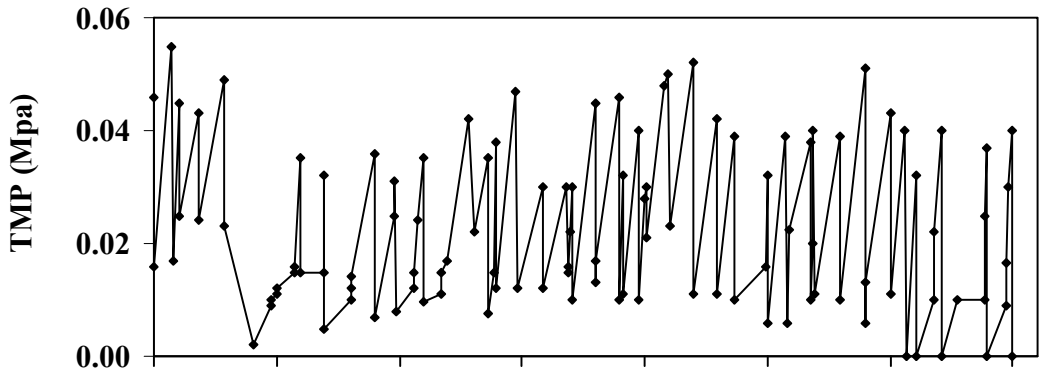

b)

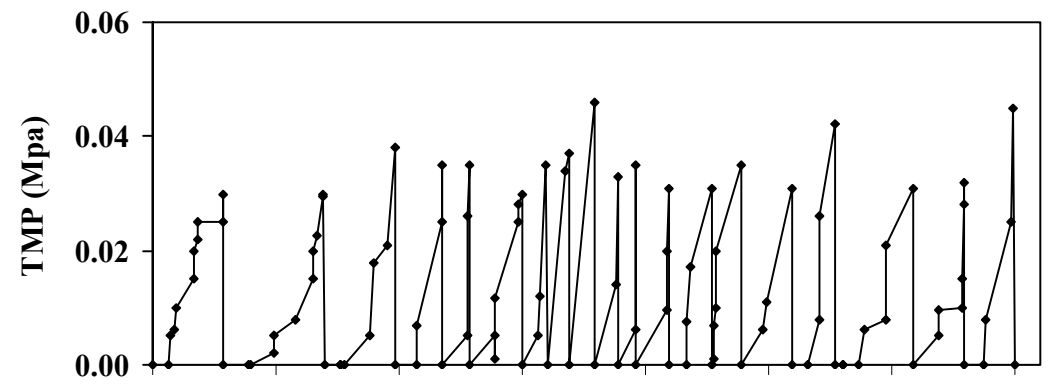

c)

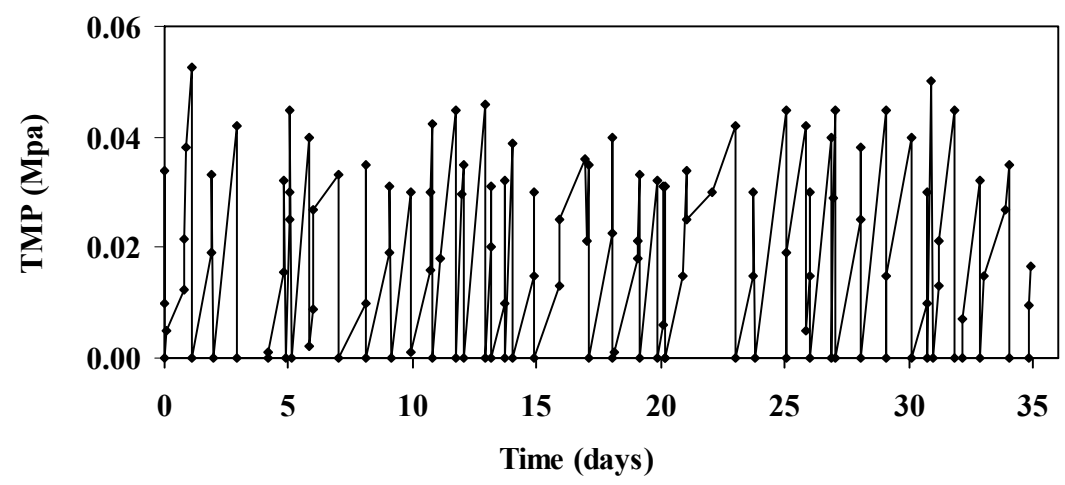

Fig. 4 - TMP profiles of MBR at a) R4, b) R5 and c) R6.

\section{TMP profiles of MBR experiments with PSI addition}

Fig. 5 shows the fouling frequency in MBR systems when PSI and sole Fe(III) coagulant were used (R7, R8, R9). From the start of PSI addition, the fouling frequencies in R8 (PSI-100) and R9 (PSI-025) had decreased gradually. After 20 days, they completely decreased as shown in Fig. 5. The mean periods per one washing in R7, $\mathrm{R} 8$, and $\mathrm{R} 9$ were $0.91 \pm 0.4$ day, $13.99 \pm 8.1$ days, and $34.97 \pm 3.28$ days, respectively. This suggested that using PSI as coagulant resulted to higher efficiency in mitigating 
membrane fouling risk than using sole Fe(III). The decrease of fouling frequency would be caused by the change of biopolymer concentrations as shown in the batch experiment results. Therefore, the biopolymers in R7, R8, and R9 were measured.

a)

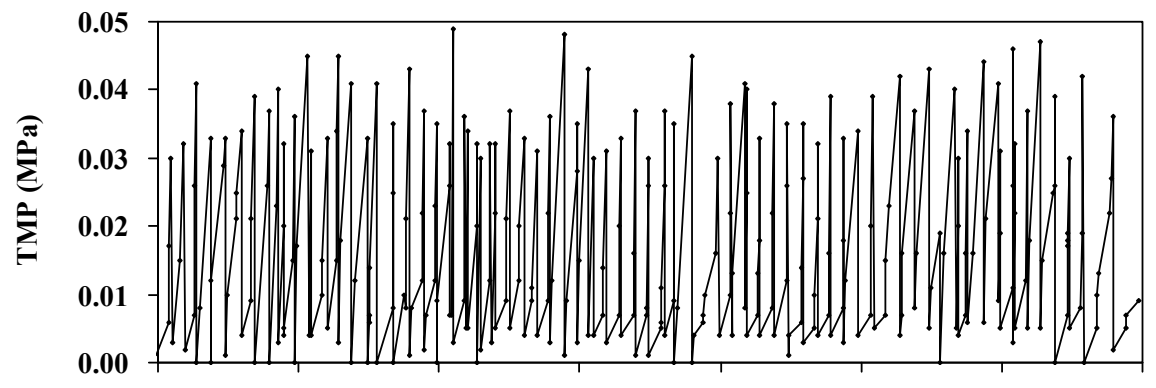

b)

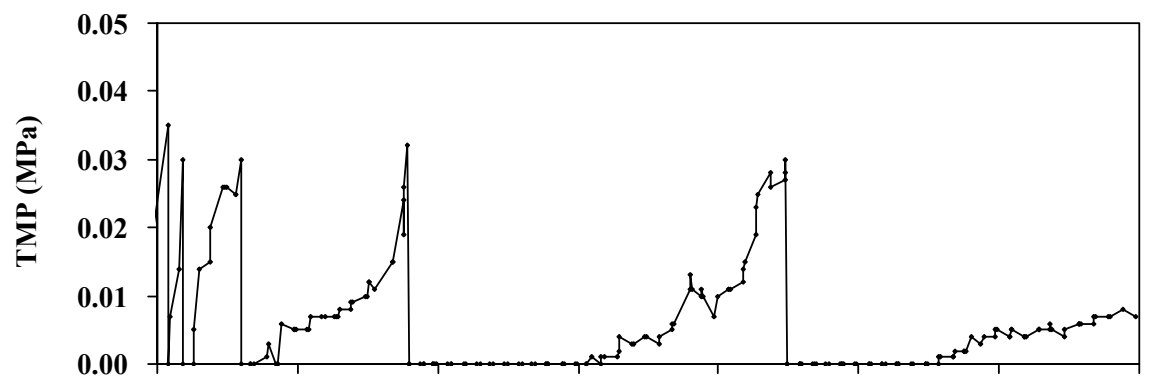

c)

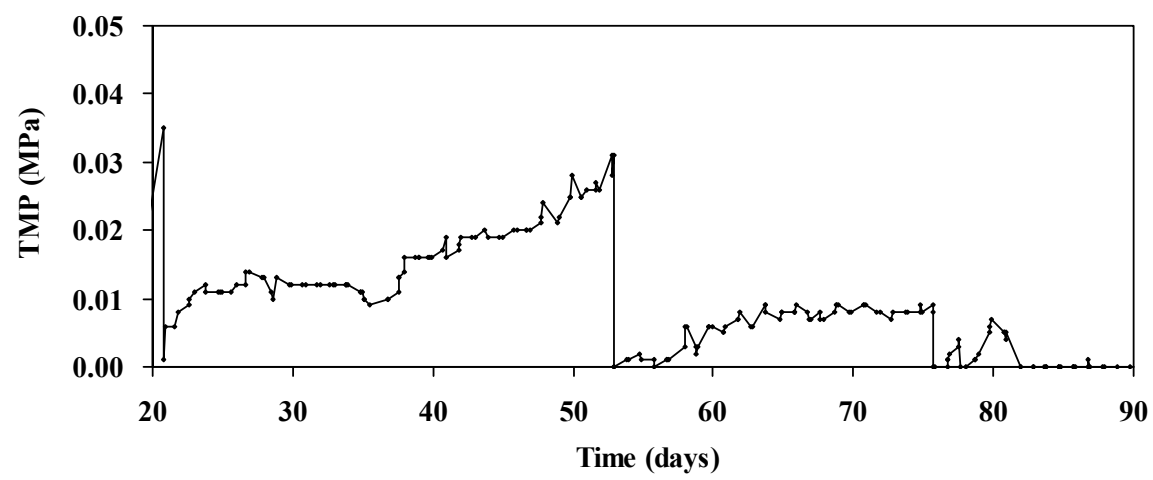

Fig. 5 - TMP profiles of MBR at a) R7, b) R8 and c) R9.

\section{Change of biopolymer in MBRs with PSI addition}

Previous studies (Le-Clech et al., 2006; Arabi and Nakhla, 2008; Zhang et al., 2008; Mishima and Nakajima, 2009) have reported that the biopolymer contents in EPS and SMP were the main factor causing membrane fouling problem. Therefore, the biopolymer contents of EPS and SMP were also measured.

As shown in Fig. 6, biopolymer concentrations, especially carbohydrate in SMP (both fractions of $<0.4 \mu \mathrm{m}$ and 1-0.4 $\mu \mathrm{m}$ ), were largely decreased by PSI-100 and PSI-025 addition. On the contrary, biopolymer concentrations in activated sludge and EPS had small differences with the addition of Fe(III), PSI-100, and PSI-025. It suggested that the PSI had affected and coagulated the SMP in the reactors and prevented the membrane from fouling. From these results, it can be stated that in the case of PSI addition, a strong correlation between membrane fouling (TMP) and the biopolymer 
concentrations was obtained.
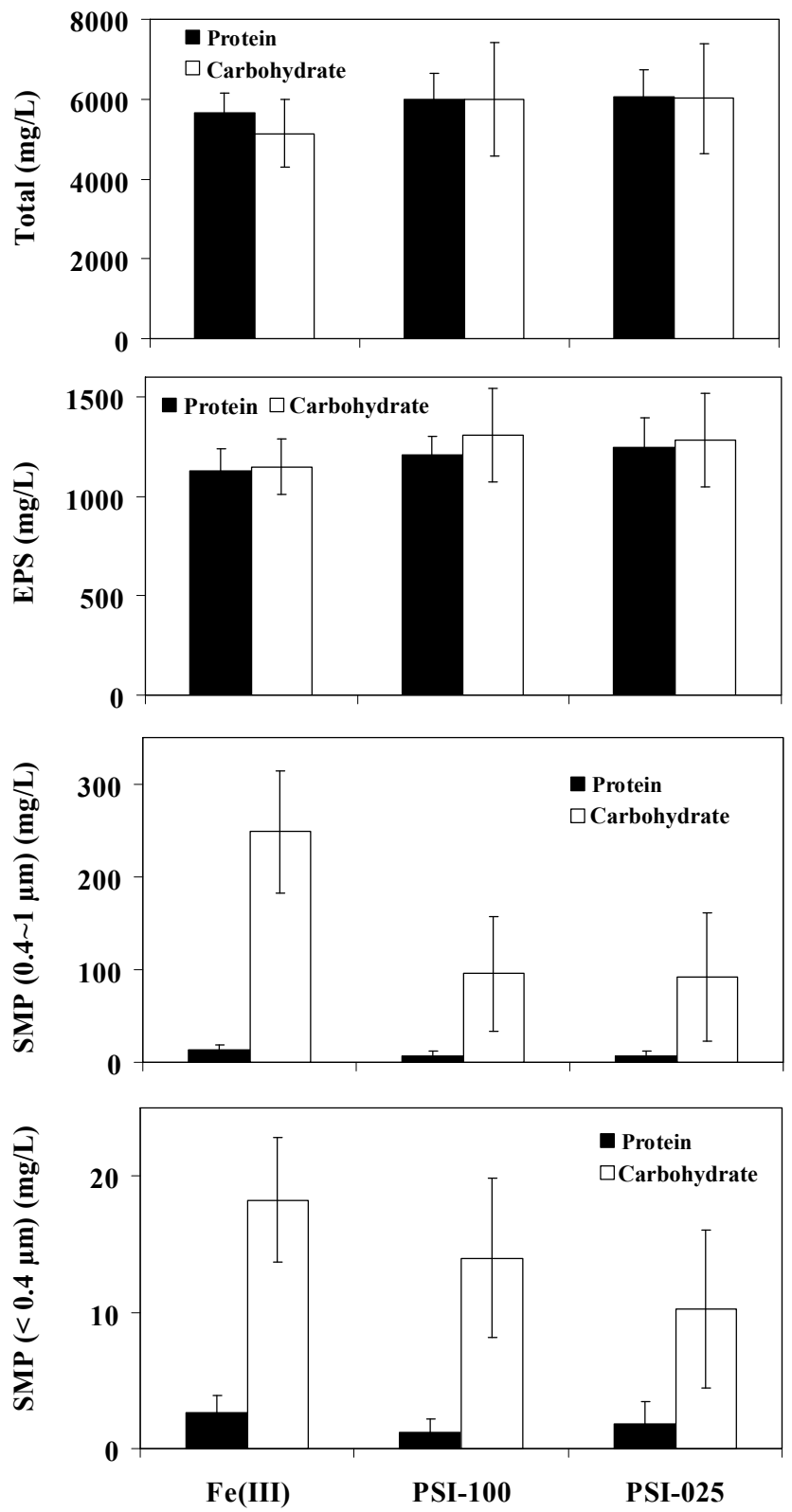

Fig. 6 - Protein and carbohydrate concentrations in R7, R8 and R9.

(Error bars show the standard deviation of 21 samples)

\section{CONCLUSIONS}

This paper investigated the effects of the coagulants and coagulant aid additions in controlling membrane fouling risk in MBR. A number of batch experiments and longterm MBR experiments were conducted and the results obtained are as follows:

Sole polysilicate addition in MBR showed no effect on the removal of biopolymer in batch experiments and on the mitigation of membrane fouling risk in MBRs. 
Mixture of polysilicate and $\mathrm{Fe}(\mathrm{III})$ with a suitable ratio gave positive effect, as compared to sole polysilicate or sole $\mathrm{Fe}$ (III) addition, on biopolymer removal and membrane fouling mitigation. This was because the presence of polysilicate served as a bridge to enhance the aggregation of $\mathrm{Fe}(\mathrm{III})$ coagulant and so the control of membrane fouling was more effective.

PSI effectively reduced biopolymer concentrations and membrane fouling in MBR. The reduction of membrane fouling by PSI addition was caused by the coagulation of SMP.

\section{ACKNOWLEDGEMENTS}

The authors would like to thank Mr. N. Shimada and Mr. Iori Mishima. Moreover, since this work was partly supported by Open Research Center Project for Private Universities matching fund subsidy from MEXT, 2007-2011, the authors are equally grateful for the research aid.

\section{REFERENCES}

Aquino S. F. and Stuckey D. C. (2008). Integrated model of the production of soluble microbial products (SMP) and extracellular polymeric substances (EPS) in anaerobic chemostats during transient conditions, Biochemical Engineering Journal, 38, 138-146.

Arabi S. and Nakhal G. (2008). Impact of protein/carbohydrate ratio in the feed wastewater on the membrane fouling in membrane bioreactors, Journal of Membrane Science, 324, 142-150.

Drews A., Mante J., Iversen V., Vocks M., Lesjean B. and Kraume M. (2007). Impact of ambient conditions on SMP elimination and rejection in MBRs, Water Research, 41, 3850-3858.

Drews A., Vocks M., Bracklow U., Iversen V. and Kraume M. (2008). Does fouling in MBRs depend on SMP? Desalination, 231, 141-149.

Duan J. and Gregory J. (2003). Coagulation by hydrolysing metal salts, Adv. Coll. Interf. Sci. 100-102, 475-502.

$\mathrm{Fu}$ Y. and Yu S. L. (2007). Characterization and coagulation performance of solid polysilicic-ferric (PSF) coagulant, Journal of Non-crystalline Solid, 353, 2206-2213.

Fu Y., Yu S. L., Yu Y. Z., Qiu L. P., Hui B. (2007). Reaction mode between Si and Fe and evaluation of optimal species in poly-silicic-ferric coagulant, Journal of Environmental Sciences, 19, 678-688.

Ichihashi O., Satoh H., and Mino T. (2006). Effect of soluble microbial products on microbial metabolisms related to nutrient removal, Water Research, 40, $1627-1633$.

Jarusutthirak C. and Amy G. (2006). Role of soluble microbial products (SMP) in membrane fouling and flux decline, Environ. Sci. Technol., 40, 969-974.

Le-Clech P., Chen V. and Fane T. A. G. (2006). Fouling in membrane bioreactors used in wastewater treatment, Journal of Membrane Science, 284, 17-53.

Meng F. and Yang F. (2007). Fouling mechanisms of deflocculated sludge, normal sludge, and bulking sludge in membrane bioreactor, Journal of Membrane Science, 305, 48-56.

Meng F., Chae S. R., Drews A., Kraume M., Shin H. S., and Yang F. (2009). Recent advances in membrane bioreactors (MBRs): Membrane fouling and membrane 
material, Water Research, 43, 1489-1512.

Mishima I. and Nakajima J. (2003). Coagulants and Phosphorus Behavior in Activated Sludge Process for Phosphorus Removal, Journal of Japan Society on Water Environment, 26(2), 99-104.

Mishima I. and Nakajima J. (2009). Control of Membrane fouling by Coagulant Addition in Membrane Bioreactor Process, Water Science and Technology, 59(7), 1255-1262.

Nakajima J. and Mishima I. (2005). Measurement of foam quality of activated sludge in MBR, Acta Hydrochim. Hydrobiol, 33(3), 232-239.

Song K. G., Kim Y., and Ahn K. H. (2008). Effect of coagulant addition on membrane fouling and nutrient removal in a submerged membrane bioreactor, Desalination, 221, $467-474$.

Tran T., Gray S., Naughton R., and Bolto B. (2006). Polysilicato-iron for improved NOM removal and membrane performance, Journal of Membrane Science, 280, 560-571.

Wang D. and Tang H. (2001). Modified inorganic polymer flocculant-PFSi: Its preparation, characterisation and coagulation behavior, Water Research, 35(14), 3418-3428.

Wu J., Chen F., Huang X., Geng W., and Wen X. (2006). Using inorganic coagulants to control membrane fouling in a submerged membrane bioreactor, Desalination, 197, 124-136.

Xu X., Yu S. L., Shi W., Jiang Z. Q and Wu C. (2009). Effect of acid medium on the coagulation efficiency of polysilicate-ferric (PSF) - A new kind of inorganic polymer coagulant, Separation and Purification Technology, 66, 486-491.

Yu S. L., Zhao F. B., Zhang X. H., Jing G. L., and Zhen X. H., (2006). Effect of components in activated sludge liquor on membrane fouling in a submerged membrane bioreactor, Journal of Environmental Science, 18(5), 897-902.

Zhang H. F., Sun B. S., Zhao X. H., and Gao Z. H. (2008). Effect of ferric chloride on fouling in membrane bioreactor, Separation and Purification Technology, 63, 341347.

Zouboulis A. I. and Moussas P. A. (2008). Polyferric silicate sulfate (PFSiS): Preparation, characterisation and coagulation behavior, Desalination, 224, 307-316. 